\title{
Lição das coisas: ruínas modernas e romance naturalista brasileiro
}

\author{
Salete de Almeida Cara ${ }^{1}$ \\ Universidade de São Paulo
}

Resumo: O estudo do romance Luzia-Homem (1903), de Domingos Olímpio (1851-1906), dando a ver as relações entre urbanização e mundo rural durante a seca cearense de 1877 a 1879, faz pensar nas particularidades do naturalismo no Brasil, a partir da posição do seu narrador como constitutiva da formação do nosso romance.

Palavras-chave: Matéria brasileira. Romance naturalista. Narrador.

Como que se percebia no abismo do espaço infindo a eterna gestação do cosmos, operoso e fecundo, em flagrante criação de mundos novos. E, na gloriosa harmonia dos astros, na expansão soberba da vida universal, a terra cearense era a nota de contraste, um lamento de desespero, de esgotamento das derradeiras energias, porque o sol sedento lhe sorvera, em haustos de fogo, toda a seiva (Domingos Olímpio, LuziaHomem).

A leitura de romances naturalistas brasileiros, atenta aos desafios acumulados pela constituição histórica da nossa prosa literária, se depara com uma etapa longa (entre as décadas de 1880 e 1900) e resultados muito diversos, mas de grande interesse. O débito desses romances em relação ao modelo francês se mescla a uma curiosa singularidade, que pede exame em cada caso, dando a ver que a experiência social particular é pressuposto material das formas literárias. No trato com seu material, dá um passo além de José de Alencar (1829-1877), um passo aquém de Machado de Assis (1839-1908), sendo também indicativo para o que virá no romance de 1930.

Ao procurar entender a feição do naturalismo no Brasil, no entanto, o romance experimental de Émile Zola cobra seu lugar e exige voltar à má compreensão de certa crítica, estrangeira e nacional, que o reduziu a um mero romance cientificista. Sendo assim, ele apenas aplicaria, com senso de fatalismo, esquemas mecânicos de patologias hereditárias,

\footnotetext{
${ }^{1}$ Doutora em Teoria Literária e Literatura Comparada pela Universidade de São Paulo, atualmente é professora livre-docente da Universidade de São Paulo, bolsista de Produtividade em Pesquisa do CNPq. Atua como consultora ad hoc do CNPq, da FAPESP e CAPES. Suas pesquisas e publicações mais recentes, com ênfase em Literatura Comparada, se dão em torno do romance naturalista francês e brasileiro, da crítica literária e do romance nos séculos XX e XXI. Entre outras publicações relacionadas ao naturalismo, prefaciou em 2014 a edição de Bom-Crioulo e lançou em 2009 o livro Marx, Zola e a prosa realista, ambos pela Ateliê Editorial. Participa desde 2007 do grupo de pesquisa Formação do Brasil Moderno, sediado na UFRJ.
} 
reforçados entre nós pelas noções de inferioridade de raças e de classes sociais como ameaças aos fundamentos da ordem moral e legal do país. A questão se torna mais complexa quando, à crítica mais conservadora, se soma a leitura de Georg Lukács nos anos de 1930, ainda que com um senso agudo da dimensão formal das obras que analisa, e que aqui não cabe tratar.

$\mathrm{O}$ fato é que, a despeito de engrossar uma visão de minoridade ficcional em relação às realizações naturalistas, Lukács nos obriga a atentar para a forma dos romances realistas e naturalistas. O que se vê, no entanto, em autores que vão de Balzac ao próprio Zola, sempre levando em conta as determinações objetivas de cada caso, é um processo de figuração das contradições e violência nas relações sociais e na conformação das subjetividades. ${ }^{2} \mathrm{O}$ romance naturalista de Zola incluiu as classes sociais espoliadas por um progresso material que, como acumulação internacional do capital (e suas crises), se configura sob a lógica da especulação açambarcando produção e consumo, domínio dos espaços públicos nas cidades, exploração das novas tecnologias e seus negócios de ultramar. ${ }^{3}$

Por certo, sendo outra a matéria a ser tratada pelo nosso naturalismo, será outra a posição do narrador que cada autor configura. Como mostra a análise de Antonio Candido, em $O$ cortiço (1890), de Aluísio Azevedo (1857-1913), romance "nutrido por uma espécie de realismo alegórico" (presente também em Zola, o procedimento tem aqui outras consequências), o próprio narrador passa a ser, ele mesmo, um problema e uma saída ficcional, expostos pelo uso de clichês imputados ao modelo e a partir (e à revelia, como resultado literário) de valores e crenças compartilhados pela nossa elite letrada do tempo:

Ainda aqui encontramos todos os chavões do tempo, marcando a ambiguidade do intelectual brasileiro que aceitava e rejeitava a sua terra, dela se orgulhava e se envergonhava, nela confiava e dela desesperava, oscilando entre o otimismo idiota das visões oficiais e o sombrio pessimismo devido à consciência do atraso. Sob esse aspecto o Naturalismo foi um momento exemplar, porque viveu a contradição entre a grandiloquência das aspirações liberais e o fatalismo de teorias então recentes e triunfantes, com base aparentemente científica, que pareciam dar um cunho de inexorável inferioridade às nossas diferenças com relação às culturas matrizes (CANDIDO, 1993, p. 136-139).

As relações do narrador com sua matéria (e suas personagens) são constitutivas da própria formação do romance brasileiro. Em Luzia-Homem (1903), de Domingos Olímpio

\footnotetext{
${ }^{2}$ Para uma visão de conjunto dos impasses enfrentados por Balzac e Zola, cf. HARVEY, 2015. Para uma leitura do realismo em Balzac, cf. ADORNO, 1984.

${ }^{3}$ Exemplos de críticas que, lendo o sentido das formas dos romances naturalistas, vão na direção contrária às avaliações de Lukács são, entre outras, as análises de Erich Auerbach (1975) e de Antonio Candido (1993). 
(1857-1906), ${ }^{4}$ aqui em questão, é o caso de observar de que modo foi possível a um abolicionista e republicano, secretário em Washington da Missão Rio Branco, morando no Rio de Janeiro desde 1890, voltar seu olhar para Sobral durante a "grande seca" do Ceará, entre 1877 e 1879, cidade onde tinha vivido até 1879 e onde foi promotor público. Assunto explorado pelo naturalismo regionalista (e depois dele), a "grande seca" transformou-se em questão social quando foi além do mundo rural e invadiu o "universo urbano 'moderno' e ‘civilizado"”, segundo afirma um estudioso: “(...) a seca adentrou o mundo do poder constituído, avançou sobre o centro imaginário deste poder, sem respeitar-lhe os 'canais competentes', e atingiu o cerne da aventura civilizatória que a elite local imaginava experimentar neste momento" (NEVES, 2000, p. 25 e 2007, p. 80-97). Como enfrentar a herança escravista, a degradação do trabalho, a exclusão dos migrantes pobres na cidade que se modernizava nas condições brasileiras?

$\mathrm{Na}$ sequência de uma estiagem de três décadas, a "grande seca" atinge a região semiárida. A guerra de Secessão norte-americana (1861-1865) abrira espaço para a produção de algodão naquela zona de pecuária, inserindo essa economia no circuito do mercado internacional, com preços controlados pelo capital comercial e financeiro da Inglaterra e Estados Unidos:



No ano em que se passa Luzia-Homem, 1878, a seca se agrava e um êxodo de famintos caminha na direção das regiões de serras úmidas e do litoral. A situação da seca escancara a relação entre espacialização mundial do espaço mercantil e violência contra a população de retirantes supérflua e descartável, dentre os quais pequenos sitiantes, posseiros e meeiros submetidos a uma estrutura que garantia os privilégios do grande proprietário como intermediário comercial e financeiro do capital internacional, do qual replica procedimentos de apropriação do lucro, além de ter modos próprios de exploração do trabalhador da terra, mantendo "o círculo infernal de sua submissão":

Fazem sua aparição grandes trustes internacionais que controlam a circulação internacional dessa mercadoria: o "abc" do Nordeste agrário

\footnotetext{
${ }^{4}$ Cf. Luzia-Homem (Martin Claret, 2003). As páginas citadas são desta edição. Uma outra versão da análise que se segue, "Luzia-Homem: um romance naturalista", foi publicada em "Leituras do romance brasileiro", na Revista $O$ eixo e a roda, Universidade Federal de Minas Gerais, vol. 22, n. 1, 2013. 
algodoeiro-pecuário começa pelas siglas Sanbra e Clayton, e essa é a alfabetização do trabalhador rural desse "Nordeste". (...) O capital internacional (...) cria, aproveitando a estrutura de reprodução do latifúndiominifúndio, um intermediário comercial que vai desempenhar a tarefa de recoletar, das milhares de pequenas plantações de algodão, os resultados da colheita: os fazendeiros, principalmente os grandes, convertem-se nesse intermediário comercial, que faz vezes também de intermediário financeiro, por conta própria ou com recursos das 'três irmãs', para financiar as entressafras, ou o período morto que medeia entre uma e outra colheita. Ele se desempenha com os mecanismos das 'três irmãs' nessa operação (...) Aduzirá a esse mecanismo um de invenção própria: financiará, em espécie, as poucas mercadorias que o meeiro não produz (...) Descontará na colheita, cobrando preços exorbitantes, esse fornecimento em espécie: no fim restará ao meeiro tão somente a sua própria força de trabalho e a de sua família, com a qual recomeçará o círculo infernal de sua submissão (OLIVEIRA, 2008, p. 169-170).

Em Luzia-Homem, essa violência de caráter objetivo não está presente. A desmedida, o horror e a irracionalidade, diminuídas e encasteladas nos conflitos folhetinescos da trama, contam com figuras pinceladas em traços socialmente inespecíficos. Vinte e sete dos vinte e oito capítulos tem como eixo a "paixão brutal" do sargento Crapiúna, uma "obsessão afrontosa, cada vez mais ardente e descomedida", numa trama de coincidências fortuitas. Seu assédio a Luzia-Homem se dá em clima de calúnias, comentários ferinos de populares, "maligna curiosidade do mulherio", infâmia como ameaça permanente, roubo, prisões, rezas milagrosas, feitiçaria e ciúmes do sargento - "martírio de onça acuada". Crapiúna será desmascarado, preso por roubo e tramoias de paixão, mais por casualidade e esperteza de uma amiga de Luzia, Teresinha, do que por bruxaria, como ela mesma acredita. No desfecho, o grupo dos amigos de Luzia e de sua mãe tentará alcançar melhores dias na serra Meruoca.

O sertão de Luzia-Homem, desvinculado da "expansão da economia mundial", 5 é visto como "nota de contraste" (...) "na gloriosa harmonia dos astros, na expansão soberba da vida universal", num "sertão tostado, como terra de maldição ferida pela ira de Deus" (OLÍMPIO, 2003, p. 19 e p. 21-22). Na escolha do enredo, o narrador, retórico e grandiloquente, mostra impasses na representação e constituição de um objeto feito de ruínas, violência social e rotina de massacre. Mergulhado num espetáculo de horror pelo qual não se sente responsável, tem como pressuposto (assim como as autoridades competentes) a "normalização" da barbárie da

\footnotetext{
${ }^{5}$ Dale Tomich assinala que "o advento da hegemonia britânica e a Revolução Industrial na Grã-Bretanha reestruturam a divisão mundial do trabalho e estimularam a expansão material da economia mundial. Esses desenvolvimentos não apenas criaram as condições para a extinção da escravidão dentro do Império britânico como também encorajaram a expansão e a intensificação da escravidão fora dele. (...) A demanda de algodão, café e açúcar atingiu proporções sem precedentes durante o século XIX, e a produção dessas safras revitalizou a escravidão em Cuba, nos Estados Unidos e no Brasil como parte dessa emergente divisão capitalista internacional do trabalho. Isso refletiu na escala e na natureza da própria produção escrava" (Cf. TOMICH,
} 2011, p. 87-89). 
seca pelas medidas do Império, para as quais a exploração do trabalho semiescravo dos retirantes é providencial mecanismo de controle social para evitar o ócio, como se dizia.

Os impasses do narrador de Luzia-Homem são os do intelectual organicamente afinado com as classes proprietárias, para as quais pouco interessava o destino daqueles que atravancavam seus negócios transatlânticos. Ao mesmo tempo, ele não desfruta (ainda que seja beneficiário) dos privilégios do proprietário colonial, que tinha um pé nos interesses internacionais e outro na administração da ralé descartável do país. É ambígua, para dizer o mínimo, a inserção do narrador na exploração e no rombo social que a grande seca deixa ainda mais visível. Na tragédia da "terra cearense" de Luzia-Homem não há opressores nem antagonismos sociais, mas assaltos a "comboios de víveres" por "bandos de famintos, malfeitores e bandidos", misturados e indiscriminadamente "organizados em legiões de famosos cangaceiros" (OLÍMPIO, 2003, p. 38).

A posição narrativa, constitutiva de uma dinâmica histórica (particular e geral), conta com a autoimagem de uma superioridade que se exerce como violência, desde o início incorporada pela própria forma narrativa, e que o desfecho irá ratificar. Trata-se de uma figuração - precária e, nessa medida, significativa - de cooptação de todas as personagens pelo narrador, estratégia que procura instalar uma espécie de voz coletiva (um arremedo de coro, a seu dispor), sustentada pela distância social com que constrói inclusive as personagens que movimentam seu enredo. Empobrecidas pela seca, elas são enquadradas por méritos morais apropriados ao passado proprietário já perdido, critério que elas mesmas compartilham e confirmam com orgulho.

Teresinha "teve bons princípios e foi bem afamilhada", segundo Raulino, foi levada à prostituição por dramas amorosos. Os avós de Raulino "poderiam comer em prato de ouro", como ele mesmo conta: "tive currais cheios de vacas de leite" e muito mais, além de sobrenome "de gente graúda, de muitas posses e honrarias, espalhada por estes sertões numa parentalha". Pretendente de Luzia, Alexandre é também "pessoa de consideração e procedente de boa família", segundo Teresinha: "Dizem que deixou morada de casa e uma fazenda nos Crateús". Luzia, filha de vaqueiro de major, tem padrinhos, simpatia do promotor, de sua mulher, e regalias no trabalho e no passadio. Todo o grupo é afeito ao trabalho digno, com forte sentido de honra e respeito às autoridades (OLÍMPIO, 2003, p. 175; 28).

Tem interesse o tipo de aliança que o narrador estabelece com essas figuras, com cargos na administração da população faminta. O procedimento narrativo de cooptação, servindo aos desígnios do narrador, forjará entre eles cumplicidades e alianças. Todos parecem partilhar 
valores comuns. No entanto, as tais cumplicidades dependem da subalternidade das personagens e do horizonte de um descarte social, aberto pelo novo estágio da ordem produtiva (que o desfecho irá explicitar, nos seus termos). Os discursos direto, indireto e indireto livre (em menor número), ao figurar cumplicidade, incluem preconceitos partilhados. Assim, o desprezo piedoso em relação aos miseráveis e à multidão de famintos malcheirosos é tratado como lugar comum: quem diz "canalha de retirantes" é a "loura, delgada e ágil" Teresinha; quem diz "cambada de retirantes nojentos e leprosos", é o sargento Crapiúna, a quem eles causam "engulhos". Mas o procedimento vai mais longe.

Também o populacho da cidade está à disposição do narrador para conferir generalidade aos seus próprios juízos, com foros de verdade, naturalizando seu ponto de vista como inevitabilidade da ordem de sentimentos gerais. Essa posição se esclarece em óbvias pinceladas. À sertaneja Luzia é dado o papel de dizer à amiga que "é pena, você, uma moça branca, andar assim na vida”. Ela, Teresinha, por sua vez, mora em quarto de parede meia com soldados de baixa patente no beco da Gangorra, onde funciona um antro de jogatina e extorsão, espelunca que reúne "operosos contribuintes da estatística criminal" e que o sargento Crapiúna frequenta com assiduidade.

Esse sargento Crapiúna, "lúbrico soldado" de "volúpia brutal" e oponente para efeitos do conflito central, compõe o grupo dos precariamente incluídos na sociedade como subalterno do poder público, do poder dos Coronéis (de quem já foi guarda-costas) e antigo caçador de cangaceiros e jagunços. Um "mulato perfumado, exibicionista", de "encanto militar" sedutor, bicaria grosseira e anel de ouro, capaz de roubo, calúnia, trovas com desenhos de corações flechados, morte e "proezas cruéis", como dizia a voz do povo (OLÍMPIO, 2003, p. 35). E mesmo o ruivo Raulino, sertanejo que é "genuíno tipo de bretão" com "distinção de tipo de outra raça" e "contador de histórias maravilhosas de grande voga" (OLÍMPIO, 2003, p. 59), só é capaz de dizer, ao ir para a serra Meruoca nomeado feitor, que o trabalho, a gratificação e a ração extra foram concedidos pelo "doutô, engenheiro das obras, que é inglês, ou alemão, não sei bem que língua ele fala" (OLÍMPIO, 2003, p. 184).

A ansiedade de Luzia (“teria má sina, mau olhado?”) é debitada pelo narrador a seu "espírito" impotente que flutuaria "à mercê de noções incompletas do bem e do mal" (OLÍMPIO, 2003, p. 85). Páginas adiante, caberá a ela um gesto de pudor ao ver na rua "mendigos nauseabundos" e "torpemente sórdidos", evitando o contato e desviando os olhos, numa reação própria de quem "ainda não se acostumara ao pungente espetáculo da miséria ínfima, degradada e feroz" (OLÍMPIO, 2003, p. 95). A longa descrição com a qual o narrador 
ratifica esse gesto da moça confirma, sobretudo, a torpeza e animalidade dos pobres "a mendigarem uma migalha, ossos, membranas intragáveis, os resíduos destinados a repasto de cães". E também das crianças "em ferozes pugilatos", pequenos animais "privados de memória", que "rugiam e mostravam os dentes roídos de escorbuto", quando contrariados. (OLÍMPIO, 2003, p. 94-95).

Finalmente, o pudor de Luzia é feito cúmplice da adesão do narrador à ordem e às ações coercitivas da polícia: "Era indispensável ativa vigilância para não serem assaltadas e devoradas as provisões à venda, pela horda de meninos, que não falavam, não sabiam mais sorrir" (OLÍMPIO, 2003, p. 95). A feição do narrador traz novidades em relação a outros romances do período sobre o mesmo assunto, como A fome (1890), de Rodolfo Teófilo. Com final feliz, cenas escabrosas, descrições de doenças com forte teor documental e cientificista (um "estranho festival de escatologias", segundo Lira Neto), A fome destaca o coronel retirante Manuel de Freitas, entre os outros retirantes moralmente frágeis, proprietário que a seca alcança sem lhe tirar a dignidade (LIRA NETO in TEÓFILO, 2002, p. 11).

A posição do narrador frente à sua matéria, no entanto, fica clara já no primeiro capítulo de três páginas do romance. Um antigo matadouro dá lugar a uma nova frente de trabalho, no “cabeço saturado de sangue, nu e árido". Ali está sendo construída a penitenciária de Sobral. ${ }^{6}$ No presente da narrativa, o "sítio de morte" do morro do Curral do Açougue "deixara de ser o sítio sinistro do matadouro e a pousada predileta de bandos de urubutingas e camirangas vorazes”. Na compressão de tempo passado e presente (antigo matadouro e penitenciária em construção), não prospera a sugestão de comparar os retirantes às reses que iam à degola "resistindo ou entregando, resignadas e mansas", nem se completa a sugestão metafórica: continua visível o mourão onde eram enroladas as cordas de laçar animais, "lúgubre vestígio" que retorna embutido na imagem na última frase do capítulo, a penitenciária como "lúgubre monumento consagrado à maldade humana" (OLÍMPIO, 2003, p. 13-15).

Nesse primeiro capítulo, o narrador cifra como trabalho escravo, denegando sem nomear, o que nomeia trabalho operário, justamente quando a seca, dizimando grande parte dos escravos que restavam na região, reforçava a exploração da mão de obra dita livre nas plantações de algodão (por volta de 1870 já chegavam imigrantes portugueses). Não causa

\footnotetext{
6 O Boletim Municipal da Prefeitura de Sobral, de julho de 2010, na seção "História da Cidade", conta com orgulho a construção emergencial da Cadeia Pública (de que trata o romance Luzia-Homem) como meio de aliviar o sofrimento dos flagelados, citando o primeiro parágrafo do romance de Domingos Olímpio. Combinado ao depoimento publicado ao lado, no mesmo Boletim, onde se louva a pujante cidade "que sempre foi vitrine da vanguarda", vê-se que a generosidade ideológica com o passado ainda implica, como sempre, esconder os fundamentos da violência.
} 
espanto que a Abolição tenha sido antecipada em quatro anos no Ceará (dez anos depois desta seca), onde se escravizavam índios e os negros serviam, sobretudo, como fonte de acumulação do capital comercial através do tráfico interno - vendas e contrabando. $\mathrm{O}$ trabalhador livre, branco ou negro, rendia mais.

As imagens da prosa escamoteiam as formas de exploração de base escravista e a violência social. Os retirantes são "legiões de operários" em "ruidosa diligência", a serviço do "castelo da prisão traçado pelo engenho de João Braga" (um protetor de Luzia que, segundo o narrador e Alexandre, é "aquele coração de ouro"). Segundo o narrador, há "trabalho para todos" na construção, além de racionalmente distribuído segundo as condições físicas de cada um. A "maldade humana” não diz respeito, portanto, ao "formigueiro" de figuras "pitorescas, esquálidas, pacientes", uma multidão com velhos, mulheres e crianças que lembram ao narrador "heroicos povos cativos, erguendo monumentos imortais ao vencedor" (OLÍMPIO, 2003, p. 13).

Nessa "melopeia do trabalho amargurado ou feliz", estranha e grotesca "ode ao trabalho" de vencedor não nomeado, cabem brincadeiras de meninas e moças, animação nos acampamentos de noite, alegria e resignação, panelas cheias, gargalhadas e assobios, cenas pitorescas, rezas agradecidas, viola e samba, e alguma "íntima revolta impotente" ou morte pontual de "algum infeliz" por extrema fadiga. É explícita sua simpatia e adesão à "penosa tarefa de distribuir socorros", desempenhada "com excepcional e caridosa dedicação" por gente rica da cidade na Comissão de Socorros, que decide por um "salário emulativo" em boas rações de comida, que são "verdadeiras gulodices para as infelizes criaturas" (OLÍMPIO, 2003, p. 14).

Vale lembrar, num parênteses, que uma das medidas do gabinete liberal Sinimbú e do senador Pompeu foi justamente a construção da via férrea que ainda hoje contorna a serra Meruoca, chegando a Sobral, e teve sua demarcação e localização controladas por interesses na ampliação do escoamento do algodão, modificando os caminhos habituais, que chegaram a ser fechados, dificultando a passagem dos retirantes. ${ }^{7}$ O dever do Estado imperial na proteção aos flagelados, garantido pela Constituição de 1824, tinha tomado a frente quando os proprietários se sentem desobrigados em relação à cultura de subsistência. Os retirantes são massacrados em subempregos na construção de obras públicas - edifícios, barragens, estradas, perfuração de poços -, no transporte de pedras em trajetos de até $10 \mathrm{~km}$ da capital e

\footnotetext{
${ }^{7}$ Para um estudo sobre a situação e a resistência dos trabalhadores durante a construção da estrada de ferro Fortaleza-Baturité, que inclui Sobral na rede de caminhos da região produtora de algodão, cf. a Dissertação de Mestrado de Wendell Guedes da Silva, A todo vapor! Formação de trabalhadores na estrada de ferro de Baturité (1877-1880). Fortaleza: Universidade Estadual do Ceará, 2013.
} 
no despejo, em condições de miserabilidade, nos seringais da Amazônia. Mas os debates do tempo sobre as medidas do governo patinam nas contorções dos homens públicos diante da miséria, evocando a solidariedade própria da tradição agrária, a caridade cristã das “comissões de socorros" e recorrem à ideologia do campo como fonte da civilização, identificada aos pressupostos do paternalismo e da lealdade dos pobres. A atual ocupação predatória da serra Meruoca em Sobral, hoje cidade polo de desenvolvimento regional, está historicamente vinculada à concentração da estrutura fundiária e à produção do algodão.

Ainda no início do romance, uma estranha figuração da cidade de Sobral lhe confere ao mesmo tempo as qualificações de intelectual e formosa, monstro e vítima, sendo depois empório comercial e oásis. Rica e populosa, ela se destaca “do perfil verde-escuro da serra Meruoca" com sua "casaria branca alinhada em ruas extensas e largas, os telhados vermelhos e as altas torres dos templos, rebrilhando em esplendores abrasados". Olhada de noite, desde o "céu límpido" e sem nuvens, vê-se a cidade cercada por "um colar de luzes tímidas, como círios melancólicos velando enorme esquife", e "adormecida em torpor de monstro saciado" (OLÍMPIO, 2003, p. 13-15). Dominando o vale, é “empório do comércio do Norte da província na qual o governo estabelecera opulentos celeiros" e "oásis hospitaleiro anelado pelas caravanas de pegureiros esquálidos" (OLÍMPIO, 2003, p. 157-158). Anote-se que as imagens de empório e celeiro eram usadas desde meados de 1860 em discursos oficiais. As imagens do 'empório" e do 'celeiro' estão presentes, em 1866, no discurso do presidente da Província, por ocasião da abertura de uma Exposição Provincial no Ceará. A exposição ia na direção do projeto do Império de integração regional (de que fez parte a Comissão Científica de 1860 referida em Luzia-Homem), respondendo ao imperativo internacional de progresso industrial, aqui com todo o peso da fraseologia e da pressão dos interesses agrários:

As festas da indústria, como as da inteligência, são sempre um grande e nobre espetáculo, no seio das nações cultas. Elas anunciam o reinado fecundo das artes da paz e as conquistas potentes da atividade humana. Assistimos hoje a uma dessas festas solenes. (...) a mão audaciosa do homem civilizado assentou os fundamentos de um florescente empório, rasgou a terra, e fecundou-a com o germe do trabalho. (...) Os recursos maravilhosos do solo do Ceará são explorados com perseverança. As serras convertem-se em ricos celeiros; os vales povoam-se, as planícies cobrem-se de casas de trabalho, onde circula a animação e a vida (HARDMAN, 1988, p. 71).

Suspensa sem solução entre intelectual, bela, pujante e assassina, o narrador destaca a imagem da cidade como vítima: a população triplica nas praças e ruas invadidas pelos retirantes, "esquálidas criaturas de aspecto horripilante (...) de uma sujidade nauseante, empapados de sangue purulento das úlceras, que lhes carcomiam a pele, até descobrirem os 
ossos, nas articulações deformadas" (OLÍMPIO, 2003, p. 22). Com suas "casas de taipa, palhoças, latadas, ranchos e abarracamentos no subúrbio", os retirantes embaçam o ideal de um espaço próprio das elites, eufóricas com a demolição da velha cidade colonial de pau a pique para dar lugar à reprodução do estilo europeu (mais tarde o norte-americano):

Mesmo sob os tamarindeiros das praças se aboletavam famílias no extremo passo da miséria - resíduos da torrente humana que dia e noite atravessava a Rua da Vitória, onde entroncavam os caminhos e a estrada real, traçada ao lado esquerdo do Rio Aracatu, até o mar (OLÍMPIO, 2003, p. 22).

Desse modo se estabelece uma contiguidade involuntária entre os retirantes no sertão das secas e os negros libertos, mulatos e imigrantes pobres dos centros urbanos do Sudeste que se modernizam. Retirantes e populacho perturbam a igreja matriz da cidade-vítima, onde "resplendia a capela mor", esculpida pelo entalhador, mestre João Francisco. "Uma série de elegantes colunas coríntias" emolduram uma "grande tela de Bindsay", e a capela tem banqueta de prata maciça e imagem da Virgem da Conceição, "padroeira da cidade, coroada de ouro, de pedrarias", com manto de estrela "bordado com carinho pelas órfãs da Casa de Caridade" (OLÍMPIO, 2003, p. 177).

A descrição dos adornos e obras da cidade intelectual tem, no entanto, peso de monta relativa, se posta ao lado de um dos causos de Raulino encaixados na trama, e aponta desconforto do letrado narrador. Segundo o causo, quando a comissão científica de 1860 chega à região, fica comprovado que a sabedoria dos homens aprende lições com burros velhos, que pregam peças na sapiência dos doutores, em terra de atraso e miséria. E o poeta Gonçalves Dias, que fazia parte da missão (para Raulino, o nome do poeta é "Gançalves") constata: "Estamos numa terra, onde os burros sabem mais do que os astrônomos" (OLÍMPIO, 2003, p. 188). O que fazer com tanta esquisitice nacional, dentre elas o próprio narrador? Suas noções e ambiguidades tomam corpo na personagem Luzia-Homem.

Moça de "espírito inculto" (segundo o narrador), "um anjo de bondade" (segundo a mulher do promotor), moça de "de respeito e de vergonha" (segundo Teresinha), cheia "de uma soberbia desmarcada" (segundo as moças da cidade, "deprimidas e infamadas pela miséria"). "Reparem que ela tem cabelos nos braços e um buço que parece bigode de homem", diz uma "velha alcoveta e curandeira de profissão", "em boniteza mete vocês todas num chinelo" (segundo um soldado), "pois é bonita moça, não tem nada de homem..." (segundo observação popular espontânea) (OLÍMPIO, 2003, p. 17-18). O pai lhe conferiu origem mestiça e estímulo para as "façanhas no campeio" que forjam seus músculos e sua força descomunal. 
Motivo de insinuações perversas e objeto de desejo, ela infla "a fantasia do populacho" no gozo grotesco de pregar apelidos, alimentar consensos pela humilhação do próximo, fustigar com "gracejos ferinos". Voz do povo, voz de Deus: assim a própria Luzia-Homem justifica seu "estigma varonil". Ainda segundo a voz popular, com um "buço de rapaz, pernas e braços forrados de pelúcia crespa (...) e ares varonis", ela poderia ser "uma virago, avessa a homens, devera ser um desses erros da natureza, marcados com o estigma dos desvios monstruosos do ventre maldito que os concebera" (OLÍMPIO, 2003, p. 26). ${ }^{8}$ A maledicência e ignorância são, no entanto, prontamente corrigidas pelo narrador.

Ele insiste no lado mulher da bela morena do sertão, deslocando ao mesmo tempo o argumento do populacho e o foco na exploração brutal do trabalho na penitenciária: "O trabalho não mete medo a Luzia-Homem”, ela mesma diz. Ao entrar no capítulo II carregando cinquenta tijolos para a construção, um francês aventureiro, tipo dado a documentar a "vida do povo, nos seus aspectos mais exóticos" pensa ver, com espanto e incompreensão, uma mulher com "uma parede na cabeça". O narrador trata logo de explicar que "os músculos de aço" eram recobertos por "formas esbeltas e graciosas das morenas moças do sertão", e que "sob os músculos poderosos de Luzia-Homem estava a mulher tímida e frágil” (OLÍMPIO, 2003, p. $167 ; 16 ; 25)$.

O francês Paul, um "misantropo devoto e excelente fabricante de sinetes", não compreende e se espanta com a força de Luzia (OLÍMPIO, 2003, p. 16), e, por isso, não parece trazer qualificações ideais para um observador da vida brasileira: o juízo europeu que o narrador preza também reforça seus sentimentos ambíguos, com mal-estar aos brios nacionais ameaçados. O narrador pretende dizer melhor do que um misantropo sobre Luzia-homem. Mas as mesmas providências que pretendem ratificar o distanciamento e superioridade do narrador, sem lastro crítico com a matéria, o incluem como parte do atraso (ainda que engatado na expansão do capital internacional) do qual não consegue se livrar, incrustado que está na matéria e na sua forma.

Ao olhar a seca e sua cidade natal, ele despreza "o povilhéu feroz", a "pobre gente" de "senso moral" abatido nas "baixas camadas da sociedade" (OLÍMPIO, 2003, p. 123). No

\footnotetext{
${ }^{8}$ No capítulo "Retórica e representação", David Harvey mostra que o mito de "mulheres sinistras, amazonas e viragos", num "imaginário de bestialidade e barbarismo femininos" se deu, na França, pelo papel das mulheres durante a Comuna de Paris, em 1871, marcando presença inclusive no romance Germinal, de Émile Zola (cf. HARVEY, 2015, p. 380). Num estudo sobre as representações da donzela-guerreira, Walnice Nogueira Galvão identifica no romance Luzia-Homem uma "tentativa, frustrada, como em muitas histórias dela, de crescer, acatar seu quinhão biológico, revestir-se de mulher, amar, desejar casar e ter filhos". Além da "energia máscula" e da força, os longos cabelos de Luzia são uma marca da donzela-guerreira (que "perde o cabelo para ganhar a guerra") (Cf. GALVÃO, 1998).
} 
entanto, as maledicências, insolências e provocações da "malta de vadias" da cidade assumem papel de agente na direção da trama, ao deflagrar instintos (Crapíuna) e princípio feminino (Luzia). Se insiste no enxerto da civilização no sertão, com referência à alta cultura para tratar a cena rústica, não pode evitar o caráter canhestro da sua intervenção; se desdenha um jornaleco provinciano, confere a ele papel na trama mirabolante, e o responsabiliza por ideologias que, certamente, são do próprio narrador. Assim circunscreve o horizonte da sua prosa nos próprios termos que ela tem a pretensão de representar à distância.

Numa cena exemplar, com todo o respeito pelas expressões regionais, conta que Terezinha "preparou a candeia de azeite de carrapato; espevitou o pavio de algodão torcido; acendeu-o, soprando com força num tição, e colocou-a no caritó". Vê na cena "tons melancólicos" e "contraste de claro e escuro", dignos de forjar o mote que traz um símile em socorro do narrador e da cena rústica e pobre: "como nas telas imortais de Rembrandt e Espanholeto, um quadro admirável e emotivo, cena íntima da pobreza sofredora e resignada" (OLÍMPIO, 2003, p. 55). ${ }^{9}$ A artificialidade da mistura nessa imposição de valor, norma moral burguesa e interior rústico torna canhestra a nobre missão de oferecer a matéria popular brasileira à contemplação pela medida da grande arte.

Ainda no âmbito desses impasses, ao trazer à cena o jornal $O$ sobralense, "mal impresso na tipografia Miragaia, a primeira estabelecida em Sobral”, delega agora ao jornaleco seus próprios juízos. A notícia impressa coroa o "drama de amor" de Luzia e Alexandre e decide seu destino, acusando Crapiúna: "Alexandre, a vítima da perversa aleivosia do soldado, que, assim, desdoura a farda dos bravos heróis do Paraguai, companheiros de jornada dos lendários Sampaio e Tibúrcio, é noivo de Luzia-Homem, a extraordinária mulher, que é uma das melhores operárias da construção da penitenciária”, diz a notícia (OLÍMPIO, 2003, p. 180; 179). Desse modo, Crapíúna afronta o panteão nacional e Luzia é louvada como excelente operária! Nação aviltada e exaltação do trabalho: eis os termos. A moça escuta a leitura da notícia e os elogios, entre ofendida e deslumbrada.

Assim, a imaginação se esgarça, pela pressão de uma matéria recortada a lâmina pelo narrador, marcando a precariedade, a falta de chão e de rumo das pretensões do homem culto, que, ao fim, mostrará rancor sanguinário. O desfecho do romance arma com o primeiro capítulo o teor de verdade do romance, com contornos imprevistos, à revelia do narrador que

\footnotetext{
${ }^{9}$ Zulmira Ribeiro Tavares destaca a "presença estrangeira" no "olhar 'civilizado', 'distanciado' de Domingos Olímpio". Segundo Zulmira, o romance mostraria "uma fratura exposta entre a descrição da 'miséria superior' com que pactua a intriga com seu elenco de personagens encabeçado por Luzia-Homem, e a outra, descoberta ao arrepio do estilo, fora da sua pontuação, nos hiatos abertos na empostação tortuosa animada indiferentemente por Rembrandts ou papangus" (TAVARES in SCHWARZ, 1983, p. 54-62).
} 
de certo modo ali se define, revelando um enredo subjacente não nomeado, numa verossimilhança a contrapelo. A escolha do eixo moral e folhetinesco não sustenta a promessa das águas onde a economia de sobrevivência agoniza. E a posição do narrador se expõe como parte de uma sociabilidade que se vale da manipulação e do desprezo dos de cima pelos de baixo, contando com a falta de horizonte social e de classe.

No último capítulo, entre a "paisagem morta" e a "exuberância magnífica da seiva" nos troncos da montanha, o "cortejo de êxodo" daqueles pauperizados, com seus parcos privilégios, se põe em marcha rumo à felicidade na serra e está a poucos passos de uma casinha entre laranjeiras. Pela estrada passam pedintes e homens carregando "o derradeiro produto da lavoura agonizante" (OLÍMPIO, 2003, p. 192). Quer queira ou não o narrador, seja por espírito espezinhador, seja por "soberbia desmarcada" de classe, alarga-se o espectro das vítimas por força da matéria que entrará pela porta dos fundos. As contorções da prosa serão qualificadas pela desordem irremediável que se instala no enredo, e que ele observará selando definitiva e cruelmente o excesso do seu distanciamento presunçoso, ele mesmo uma ilusão.

Luzia tomou um atalho, aliviada "pela florescência dos instintos sagrados e do afeto redentor", vendo ao longe a penitenciaria, quase pronta, onde muitos ficariam "encarcerados como em sepultura de pedra e cal". Vislumbra o sertão, as fazendas abandonadas, a "planície devastada e quieta como um imenso pântano". A certa altura, o narrador tinha indicado, pelo indireto livre, que Luzia pressentia que "talvez tombasse, como os míseros, cujas ossadas alvejantes, descarnadas pelos urubus e carcarás, iam marcando o caminho das vítimas da calamidade" (OLÍMPIO, 2003, p. 192; 194; 23). Mas o desfecho será mais inesperado e assustador.

Crapíúna, transformado pelo diz-que-diz-que de "pelintra quente e apaixonado, em reles monstro horripilante", aparece fugido da cadeia e quer vingança. Ao ver Luzia, "magnífica de vigor e beleza", confessa "quase súplice", em "insânia desesperada", que não quer "lhe fazer mal...sou um desgraçado, um miserável...” (OLÍMPIO, 2003, p. 195). Luzia avança com agressividade, forçando passagem, e joga o monstro "ébrio de luxúria" ao chão, subjugado, "medonho", enquanto tenta deter as mãos que rasgam seu vestido numa "voracidade comburente de beijos". Brutalidade, passionalidade e irracionalidade ligam, numa mesma estrutura, os “dois lutadores”, destruindo a ilusão do grupo de estar a salvo da barbárie.

Os termos do narrador ainda são morais, mas a negatividade da cena sela, retrospectivamente, a verdade de uma prosa melodramática gestada no horror, na qual agora os pequenos proprietários empobrecidos e os miseráveis formam sistema. A violência sobe a 
serra prometida e se espraia por toda a narrativa, recolhendo o chão encharcado e pretejado pelo sangue do matadouro, e ganhando um alcance que o narrador não poderia explicitar. Aquele "sítio de morte" do Curral do Açougue assombra a cena, e o esforço de sobrevivência é impossibilidade que desmente a "melopeia do trabalho amargurado ou feliz" na penitenciária.

A fantasmagoria que o romance desenhava por linhas tortas tem caráter objetivo, explicitando a posição narrativa que se sente a salvo dela, conivente com a aniquilação da vida produtiva e de suas personagens. Luzia-Homem e Crapiúna, a trabalhadora exemplar e o soldado que desonra os brios nacionais são igualmente descartados, numa luta de morte. "Crapíúna, louco de dor, embebera-lhe no peito a faca, e caía com o rosto mutilado, deforme, encharcado de sangue" rumo ao precipício. Na mão direita da moça esfaqueada, "encastoado entre os dedos, encravado nas unhas, extirpado no esforço extremo da defesa, estava um dos olhos de Crapiúna, como enorme opala esmaltada de sangue, entre filamentos dos músculos orbitais e os farrapos da pálpebra dilacerada". Diante da "divina cabeça da heroína morta", Raulino também tem “crispações medonhas de fera” (OLÍMPIO, 2003, p. 196-197).

A violência do narrador que observa o descarte das suas personagens é, ela mesma, um limite e um problema, ao figurar o horror como inevitável, da ordem de uma fatalidade consentida, a ser aceita. Para os homens livres pobres, nenhuma perspectiva no horizonte, nenhuma promessa de futuro. Vale a pena pensar no sentido objetivo e histórico dessa violência, conivência e consentimento. $\mathrm{O}$ desfecho reafirma a ilusão do não pertencimento do narrador na iniquidade das relações sociais locais, dando a ver seus termos e condições. E confirma que, a cada ciclo histórico do capital, os modos como a forma narrativa internaliza a base material da experiência podem levar com que ela dê as caras a duras penas, com teor de verdade com contornos imprevistos, a contrapelo, atrelado a insuficiência estética.

O próprio escritor por certo não poderia confirmar a intuição que, às custas da posição problemática do seu narrador, mantém o interesse do romance para leitores contemporâneos, ao mostrar os desafios de uma representação que engata o processo de urbanização nas ilegalidades e na violência do passado rural brasileiro. As providências do Estado quanto aos retirantes serão ampliadas na seca de 1932: construção de campos de concentração pelo governo local, em alianças políticas com os interesses do governo federal. Os campos de concentração foram desativados em 1933, mas, quatro anos depois, o de Crato era alvo de um massacre que dizimou o grupo que ali se organizara, em torno de um trabalho coletivo, 
chefiado pelo beato José Lourenço. Foi um campo de concentração que deu origem a uma das maiores favelas de Fortaleza hoje (RIOS, 2000).

\section{Referências bibliográficas:}

ADORNO Theodor. Lecture de Balzac. In: Notes sur la littérature. Paris, Flammarion, 1984.

AUERBACH, Erich. Mimesis. 2. ed. ver. São Paulo: Perspectiva, 1975.

CANDIDO, Antonio. O discurso e a cidade. São Paulo: Duas Cidades, 1993.

GALVÃO, Walnice Nogueira A donzela-guerreira: um estudo de gênero. São Paulo: Senac, 1998.

HARDMAN, Francisco Foot. Trem Fantasma: a modernidade na selva. São Paulo: Companhia das Letras, 1988.

HARVEY, David. Paris, capital da modernidade. Trad. Magda Lopes. São Paulo: Boitempo, 2015.

NEVES, Frederico de Castro. A multidão e a história: saques e outras ações de massas no Ceará. Rio de Janeiro: Relume-Dumará, 2000.

A miséria na literatura: José do Patrocínio e a seca de 1878 no Ceará. Revista Tempo, Niterói, RJ: Universidade Federal Fluminense, n. 22, 2007, p. 80-97.

OLÍMPIO, Domingos. Luzia-Homem. São Paulo: Martin Claret, 2003 [1903].

OLIVEIRA, Francisco de. Elegia para uma re(li)gião. Sudene, Nordeste. Planejamento e conflitos de classes. In: Noiva da revolução/Elegia para uma re(li)gião. São Paulo: Boitempo Editorial, 2008, 135-196.

RIOS, Kenia de Souza. Campos de concentração no Ceará: isolamento e poder na seca de 1932. Fortaleza: Museu do Ceará, 2000.

SILVA, Wendell Guedes da. A todo vapor! Formação de trabalhadores na estrada de ferro de Baturité (1877-1880). Fortaleza: Universidade Federal do Ceará, 2013. (Dissertação de Mestrado).

TAVARES, Zulmira Ribeiro. Rembrandts e papangus. In: SCHWARZ, Roberto (Org.). Os pobres na literatura brasileira. São Paulo: Brasiliense, 1983.

TEÓFILO, Rodolfo. A fome. Introdução Lira Neto. Fortaleza: Edições Demócrito Rocha, 2002.

TOMICH, Dale W. Pelo prisma da escravidão: trabalho, capital e economia mundial. Trad. Antonio de Pádua Danesi. Rev. técnica Rafael de Bivar Marquese. São Paulo: Edusp, 2011. 


\title{
Lesson of things: modern ruins and the Brazilian naturalist novel
}

\begin{abstract}
The study of the novel Luzia-Homen (1903), by Domingos Olímpio (1851-1906), as it reveals the connections between urbanization and the rural world during the drought in Ceará from 1877 to 1879, makes on think about the specificities of Brazilian naturalismo, by means of narrator's postition as constitutive o our novel formation.
\end{abstract}

Keywords: Brazilian substance. Naturalist novel. Narrator.

Recebido em: 15 de agosto de 2015 .

Aprovado em: 20 de novembro de 2015 . 